\title{
Second Generation Antipsychotics in the Treatment of Major Depressive Disorder: An Update
}

\author{
Sheng-Min Wang ${ }^{1,2}$, Changsu Han ${ }^{3}$, Soo-Jung Lee ${ }^{1}$, Tae-Youn Jun ${ }^{1}$, Ashwin A Patkar ${ }^{4}$, Prakash S \\ Masand $^{5}$, and Chi-Un Pae ${ }^{1,4, *}$ \\ ${ }^{1}$ Department of Psychiatry, The Catholic University of Korea College of Medicine, ${ }^{2}$ International Health Care Center, Seoul St. Mary's \\ Hospital, The Catholic University of Korea College of Medicine, Seoul, ${ }^{3}$ Department of Psychiatry, College of Medicine, Korea University, \\ Korea, ${ }^{4}$ Department of Psychiatry and Behavioural Sciences, Duke University Medical Center, Durham, NC, ${ }^{5}$ Global Medical Education, \\ New York, NY, USA
}

Less than one third of patients who suffer from major depressive disorder (MDD) report remission following antidepressant treatments requiring more diverse treatment approaches. Augmentation of second generation antipsychotics (SGAs) has been increasingly recognized as an important treatment option. The authors have previously provided a comprehensive review of SGAs for the treatment of MDD in 2013. Since then, numerous additional clinical trials have been conducted to investigate diverse issues regarding the utility of SGAs in MDD. Moreover, a new SGA, brexpiprazole, was recently approved by the Food and Drug Administration in July 2015 for the treatment of MDD as an augmentation agent to antidepressants. Thus, the aim of this study was to provide a concise update of all the available SGAs for the treatment of MDD, in particular on the additional clinical trials which have been published since 2013 .

Key Words: Antidepressive Agents; Depressive Disorder; Clinical Trial; Antipsychotic Agents; Depressive Disorder, Treatment-Resistant

This is an Open Access article distributed under the terms of the Creative Commons Attribution Non-Commercial License (http://creativecommons.org/licenses/by-nc/4.0) which permits unrestricted non-commercial use, distribution, and reproduction in any medium, provided the original work is properly cited.

\section{Article History:}

Received May 18, 2016

Revised June 15, 2016

Accepted June 16, 2016

\section{Corresponding Author:}

Chi-Un Pae

Department of Psychiatry, Bucheon St. Mary's Hospital, The Catholic University of Korea College of Medicine, 327 Sosa-ro, Wonmi-gu, Bucheon 14647, Korea Tel: $+82-32-340-2140$

Fax: +82-32-340-2255

E-mail: pae@catholic.ac.kr

\section{INTRODUCTION}

With the evolution of antidepressants development from monoamine oxidase inhibitors (MAOI) and tricyclic antidepressants (TCA) to selective serotonin reuptake inhibitors (SSRIs), the safety and tolerability of antidepressants have improved greatly. ${ }^{1}$ Although diverse antidepressants are increasingly available in the market, more than $30 \%$ of patients with depression still do not receive a satisfactory response. ${ }^{2}$ Therapeutic lag, about 2-4 weeks, often observed between antidepressant administration and the onset of clinical improvement is another problem with conventional antidepressants. ${ }^{3}$ Diverse antidepressants selectively targeting multiple receptors/transporters such as serotonin norepinephrine reuptake inhibitors (SNRI), norepinephrine-dopamine reuptake inhibitor (NDRI), serotonin partial agonist-reuptake inhibitors (SPARI), and others were developed but failed to solve the above important obstacles caused by multifactorial etiologies of major depressive disorder (MDD). ${ }^{4-12}$ See Fig. 1 for evolution

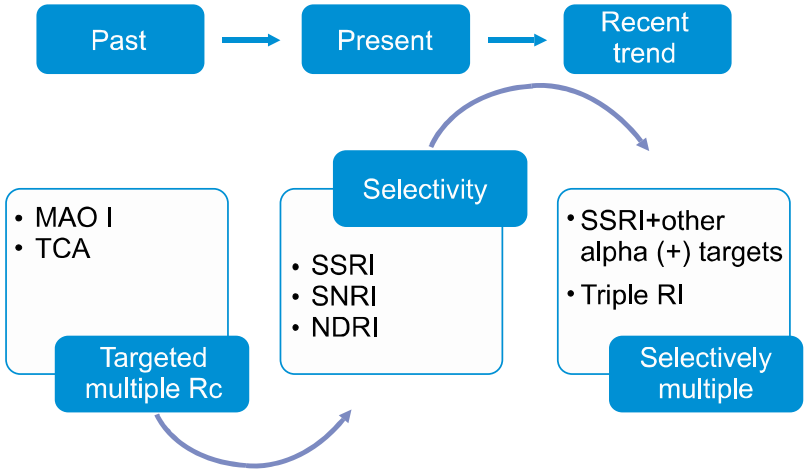

FIG. 1. Evolution of antidepressant. MAOI: monoamine oxidase inhibitors, NDRI: norepinephrine-dopamine reuptake inhibitor (NDRI), Rc: receptors, RI: reuptake inhibitor, SNRI: norepinephrine reuptake inhibitor, SSRI: selective serotonin reuptake inhibitors, TCA: tricyclic antidepressants. 
of antidepressants.

There has been substantial progress in the search for further treatment strategies for treatment-resistant MDD (TRD); psychotropics augmentation other than antidepressants, and antidepressant switches and combinations regardless of antidepressant classes. Among them, augmentation treatment with atypical antipsychotic agents has been recognized as an important option. Moreover, second generation anti-psychotics (SGAs) have been an area of focus after successful augmentation using risperidone to SSRIs was found in $1991{ }^{13}$ Thereafter, three SGAs including olanzapine (2007), quetiapine extended release extended release (2007) and aripiprazole (2009) were approved by the US FDA as an augmentation therapy to antidepressants for treating MDD. In this respect, we have previously provided a comprehensive review of second-generation antipsychotics in the treatment of MDD, which was published in 2013 . $^{14}$

Our previous review included the state of the current market, rationales for the action mechanisms of SGAs for MDD, an overview of the clinical trial data of SGAs for treating MDD, and clinical issues rose in the use of SGA therapy in patients with MDD in clinical practice. Thereafter, brexpiprazole, a dopamine D2 receptor partial agonist, was recently approved by the US Food and Drug Administration (FDA) on the $10^{\text {th }}$ of July 2015 for the treatment of schizophrenia and for an adjunctive therapy to antidepressants for the treatment of major depressive disorder (MDD). ${ }^{15}$ Thus, we aimed to provide a concise update of SGAs in the treatment of MDD by focusing mainly on the additional clinical trials which have been published since our last review.

\section{DATA SEARCH}

The search terms used for the PubMed database included 'aripiprazole', 'olanzapine', 'quetiapine', 'amisulpride', 'asenapine', 'iloperidone', 'lurasidone', 'paliperidone', 'risperidone', 'sertindole', and 'ziprasidone'. In addition, we added 'brexiprazole', and 'cariprazine', which were not included in our previous review. These terms were matched with 'depression', 'MDD', 'dysthymia', 'psychotic depression' and 'antidepressant'.

Although our previous studies were published in January 2014, the paper was written in 2013. Thus, we tried to focus this update on studies published since January 2013. In order to do so, randomized, placebo and/or comparator controlled clinical trials were principally considered for our review, so open-label studies, case reports, studies less than 20 participants, studies not including MDD, and post-hoc analyses were not included unless they were concluded by the authors to be relevant to the discussion in this review. Studies conducted in patients having schizoaffective disorders, schizophrenia, and bipolar disorders were also excluded.

The studies searched for and reviewed were all published in peer-reviewed journals in English. The reference lists from searched for and identified articles were also cross checked to find further studies. The data search and verification was handled by senior authors (CU Pae and C Han) and independently reassessed by coauthors (SJ Lee and TY Jun).

\section{THE CURRENT MARKET STATUS}

Until recently, only 3 SGAs aripiprazole, quetipaine XR and olanzapine had a formal US FDA approval in the treatment of MDD. Among them, olanzapine was approved for the treatment of TRD, which is defined as MDD patients who did not respond to two separate trials of two or more than two antidepressants after an appropriate duration and dose, as a combined agent with fluoxetine. As stated earlier, Brexpiprazole just recently received FDA approval not only for schizophrenia, but also for the treatment of MDD as an adjunctive therapy to antidepressants in July 2015 , which is the biggest change since $2013 .{ }^{15}$ In addition, a RPCT was recently published for ziprasidone and lurasidone. A RPCT regarding asenapine, cariprazine, iloperidone, and sertindole have still not been published.

The General information on SGA, including the current market situation for MDD is summarized in Table 1.

\section{Individual SGAs}

1) SGAs having US FDA approval in the treatment of MDD

(1) Brexiprazole: Brexpiprazole is a dopamine $D_{2}$ receptor partial agonist. It was recently approved by the US Food and Drug Administration (FDA) on the $10^{\text {th }}$ of July, 2015 for the treatment of schizophrenia and as an adjunctive therapy to antidepressants for the treatment of major depressive disorder (MDD). ${ }^{15}$ Studies have shown that brexpiprazole has lower intrinsic activity at the dopamine D2 receptor and has an approximately 10-fold higher affinity for serotonin 5-HT1A and 5-HT2A receptors than aripiprazole. $^{16}$

Numerous clinical trials investigating brexpiprazole in the treatment of depression have been completed and are still on going. Among them, two phase III clinical trials have been recently published (Table 1). The two studies were identical in design and were conducted by the same research group. ${ }^{17,18}$ In both studies, subjects included had a history of inadequate response to 1-3 treatment trials of standard antidepressant medications for their current depressive episode. Moreover, all patients entered a prospective 8-week phase on physician-determined, open-label antidepressant therapy (ADT). Those with inadequate response were randomized to receive antidepressants with brexpiprazole or with a placebo for 6 weeks. The primary outcome measure was changed from the baseline to week 6 according to the Montgomery-Asberg Depression Rating Scale (MADRS) total score. The first study showed that brexpiprazole $3 \mathrm{mg} /$ day led to a greater improvement in the MADRS total score than the placebo $(-8.29$ vs. -6.33 ; $\mathrm{p}=.0079$ ). However, brexpiprazole $1 \mathrm{mg} /$ day did not show 
TABLE 1. General information of second generation antipsychotic in the treatment of major depressive disorder ${ }^{\mathrm{a}}$

\begin{tabular}{|c|c|c|c|c|}
\hline Drug & FDA Indication & Possible action mechanism & Dose range & $\begin{array}{c}\text { Level } \\
\text { ofevidence }\end{array}$ \\
\hline Aripiprazole & $\begin{array}{l}\text { Augmentation } \\
\text { toantidepressants }\end{array}$ & $\begin{array}{l}\text { 5-HT1A/2C receptor partial agonism, 5-HT2A/2B receptor antag- } \\
\text { onism, 5-HT6 receptor antagonism, weak 5-HT7 receptor antago- } \\
\text { nism, D2/3 receptor partial agonism, neuroprotective effects }\end{array}$ & $5-15 \mathrm{mg} / \mathrm{day}$ & 1 \\
\hline Brexiprazole & $\begin{array}{l}\text { Augmentation } \\
\text { toantidepressants }\end{array}$ & $\begin{array}{l}\text { Partial agonist activity at serotonin } 5 \text {-HT1A and dopamine D2 } \\
\text { receptors, and antagonist activity at serotonin 5-HT2A receptors }\end{array}$ & $1-3 \mathrm{mg} /$ day & 1 \\
\hline Olanzapine & $\begin{array}{l}\text { Combination with } \\
\text { fluoxetine for TRD }\end{array}$ & 5-HT2A/2C receptor antagonism, 5-HT7 receptor antagonism & $5-20 \mathrm{mg} /$ day & 1 \\
\hline Quetiapine XR & $\begin{array}{l}\text { Augmentation } \\
\text { toantidepressants }\end{array}$ & $\begin{array}{l}\alpha-2 \text { receptor antagonism, norepinephrine transporter } \\
\text { inhibition(metabolite), 5-HT7 receptor antagonism }\end{array}$ & $50-300 \mathrm{mg} /$ day & 1 \\
\hline Amisulpride & None for MDD & 5-HT7 antagonism, presynaptic D2/3 autoreceptors antagonism & $50 \mathrm{mg} / \mathrm{day}$ & 1 \\
\hline Asenapine & None for MDD & $\begin{array}{l}\text { 5-HT2C/2A receptor antagonism, } 5 \text {-HT6/7 receptor antagonism, } \\
5 \text {-HT2B receptor antagonism, } \alpha-2 \text { receptor antagonism, partial } \\
\text { agonism at 5-HT1A receptor }\end{array}$ & Not available & 4 \\
\hline Cariprazine & None for MDD & $\begin{array}{l}\text { D2/3 receptor partial agonism, 5-HT1A receptor partial agonism, } \\
\text { 5-HT2A /5-HT7 receptor antagonism }\end{array}$ & $0.1-4.5 \mathrm{mg} / \mathrm{day}$ & 4 \\
\hline Iloperidone & None for MDD & 5-HT2A receptor antagonism, 5-HT6/7 receptor antagonism & Not available & 4 \\
\hline Lurasidone & None for MDD & $\begin{array}{l}\text { 5-HT7 receptor antagonism, } 5 \text {-HT1A receptor partial agonism, } \\
\text { weak } 5 \text {-HT2C receptor antagonism, weak } \alpha-2 \text { receptor antago- } \\
\text { nism }\end{array}$ & & 1 \\
\hline Paliperidone & None for MDD & $\begin{array}{l}\text { 5-HT2A receptor antagonism, } \alpha-2 \text { receptor antagonism, } \\
\text { 5-HT7 receptor antagonism }\end{array}$ & $3 \mathrm{mg} /$ day & 4 \\
\hline Risperidone & None for MDD & $\begin{array}{l}\text { 5-HT2A receptor antagonism, } \alpha-2 \text { receptor antagonism, } \\
\text { 5-HT7 receptor antagonism }\end{array}$ & $0.5-3.0 \mathrm{mg} /$ day & 1 \\
\hline Sertindole & None for MDD & 5-HT2A receptor antagonism, 5-HT6/7 receptor antagonism & Not available & 4 \\
\hline Ziprasidone & None for MDD & $\begin{array}{l}\text { 5-HT2A/2C receptor antagonism, 5-HT1A receptor agonism, } \\
\text { serotonin/norepinephrine/dopamine transporter inhibition }\end{array}$ & $80-160 \mathrm{mg} /$ day & 1 \\
\hline
\end{tabular}

${ }^{\mathrm{a}}$ Table adapted from article by Han et al. ${ }^{14} \mathrm{~b}$ Level of evidence defined based on the CANMAT guideline, Level 1: Meta-analysis or replicated double-blind (DB), randomized controlled trial (RCT) that includes a placebo condition, Level 2: At least one DB- randomized controlled trial (RCT) with placebo or active comparison condition, Level 3: Prospective uncontrolled trial with at least ten or more subjects; Level 4: Anecdotal reports or expert opinion.

TABLE 2. Published Phase III randomized controlled double-blind studies of brexpiprazole in treatment of major depressive disorder

\begin{tabular}{ccccccc}
\hline $\begin{array}{c}\text { Author } \\
\text { (year) }\end{array}$ & Design & Duration & Dosage & N & $\begin{array}{c}\text { Primary } \\
\text { outcome }\end{array}$ & Results \\
\hline Thase $(2015)^{17}$ & Aug in TRD & $\begin{array}{c}6 \text { weeks } \\
(+8 \text { wk OL) }\end{array}$ & $\begin{array}{l}\text { BPX 1 mg/d } \\
\text { BPX 3 mg/d }\end{array}$ & $\begin{array}{l}213 \\
\text { PBO }\end{array}$ & MADRS & BPX 3 mg > PBO in MADRS improvement (p=.0079) \\
& & & 203 & & BPX 1 mg=PBO in MADRS improvement \\
Thase $(2015)^{18}$ & Aug in TRD & 6 weeks & BPX 2 mg/d & 175 & MADRS & BPX 2 mg > PBO in MADRS improvement (p=.0002) \\
& & $(+8$ wk OL) & PBO & 178 & & \\
\hline
\end{tabular}

Aug: augmentation, BPX: brexpiprazole, MADRS: montgomery-åsberg depression rating scale, OL: open label, PBO: placebo, TRD: treatment resistant depression.

superior results compared to the placebo $(-7.64$ vs. -6.33 ; $\mathrm{p}=.0737)$. In terms of adverse reactions, mean changes from the baseline on the Abnormal Involuntary Movement Scale (LS mean difference $=0.08 ; \mathrm{p}=.0141$ ) and the Barnes Akathisia Rating Scale (LS mean difference $=0.17 ; \mathrm{p}=.0001$ ) total scores were significantly greater in the brexpiprazole $3 \mathrm{mg} /$ day group than in the placebo group. In the second study, brexpiprazole $2 \mathrm{mg} /$ day showed superior efficacy over the placebo in changes from the baseline to week 6 in the MADRS total score ( -8.36 vs. $-5.15 ; \mathrm{p}=.0002)$. Brexpiprazole improved according to the Sheehan Disability Scale (SDS) mean score versus the placebo as well $(-1.35$ vs. $-0.89 ; \mathrm{p}=.0349)$. The most common treatment-related adverse events (TAEs) were weight gain (brexpiprazole, $8.0 \%$; placebo, $3.1 \%$ ) and akathisia ( $7.4 \%$ vs. $1.0 \%$ ). Overall, brexpiprazole augmentation was safe and well tolerated in two phase III RCTs (Table 2).

(2) Aripirazole: Aripiprazole was the first SGA to receive 
US FDA approval as an augmentation therapy to antidepressants for the treatment of MDD in November 2007. Consequently, the clinical benefits of adjunctive aripiprazole for treating patients with MDD has been shown in the numerous open label and RPCTs. ${ }^{19}$ Three identically designed initial phase RPCTs showed that aripiprazole augmentation was superior over placebo augmentation in the treatment of MDD patients with 1-3 historical failures in adequate antidepressant trials. ${ }^{20-22}$

A post hoc analysis of these 3 RPCTs, which was recently published in 2014, investigated the efficacy and safety of aripiprazole augmentation for standard antidepressant treatment (ADT) in MDD patients with a prior, inadequate response to one to three ADTs. ${ }^{23}$ Patients received the prospective ADT for 8 weeks. Thereafter, patients were classified as 'ADT minimal improvers' defined as patients who maintained a CGI-I score of 3 at weeks 6 and 8 of phase B, and 'ADT non-improvers' defined as patients with a CGI-I score of 4 at weeks 6 and 8. These patients received either a placebo or aripiprazole augmentation for 6 weeks. The results showed that response rate for ADT minimal improvers receiving adjunctive aripiprazole was higher than in the placebo group $(38.8 \%$ vs. $26.6 \% \mathrm{p}<0.05)$. The remission rate was also higher for aripiprazole than for the placebo adjunctive in ADT non-improvers (24.0\% vs. $10.3 \%$, $\mathrm{p}<0.05)$. The most common adverse events for ADT minimal improvers and non-improvers receiving adjunctive aripiprazole were akathisia, restlessness and insomnia. In another study, which pooled same 3 PRCTs, stratified patients based MADRS total score (mild, $\leq 24$; moderate, 25-30; severe, $\geq 31){ }^{24}$ The study showed that aripiprazole produced greater improvement than the placebo in the MADRS total score regardless of MDD severity at the baseline. Moreover, adjunctive aripiprazole increased the likelihood of response in all subgroups. Another pooled study investigated the efficacy of adjunctive aripiprazole in patients with MDD whose symptoms worsened with antidepressant monotherapy. ${ }^{25}$ The study included 1065 patients who did not show a positive response with ADT monotherapy ( $\mathrm{N}=160$ for whose symptoms worsened and N=905 whose depressive symptoms showed no change). Adjunctive aripiprazole showed greater efficacy over the placebo in response rate (36.6\% vs. $22.5 \%)$ and remission rate $(25.4 \%$ vs. $12.4 \%$ ) for ADT-Worseners. Similarly superior efficacy of aripiprazole in response rate (37.5\% vs. $22.5 \%)$ and remission rate $(29.9 \%$ vs. $17.4 \%)$ were noted for ADT-Non-Worseners.

Since January 2013, two more RPCTs studying the efficacy of aripiprazole adjunctive use in the treatment of MDD were published. ${ }^{26}$ The first study, The Aripiprazole Depression Multicenter Efficacy (ADMIRE) study, was designed to evaluate the efficacy and safety of aripiprazole augmentation in Japanese patients with MDD. ${ }^{27}$ Subjects with an inadequate response to 8 weeks of ADT were randomized to receive placebo augmentation, fixed dose aripiprazole, or flexible dose aripiprazole for 6 weeks. The primary efficacy endpoint was mean change in the MADRS total score from the end of prospective treatment (baseline) to the end of randomized treatment. The result showed the mean MADRS total scores improved more significantly in the aripiprazole fixed and flexible groups than in the placebo group. Aripiprazole was well tolerated, and the majority of AEs were mild (aripiprazole flexible dose 59.3\%, fixed dose $54.8 \%$, placebo $48.7 \%$ ) or moderate $(17.0 \%, 15.7 \%$, $10.8 \%$ ) in severity. However, higher rate of akathisia was a concern (aripiprazole flexible dose $36.6 \%$, fixed dose $14.2 \%$, and placebo $4.1 \%$ ). A subgroup post-hoc analysis further showed that the efficacy was consistently greater with aripiprazole than placebo and was not related to any clinical factors such as gender, age, number of adequate $\mathrm{ADT}$ uses for the current episode, diagnosis of MDD, number of depressive episodes, current episode duration, onset age of MDD, elapsed time after the first episode of MDD, type of SSRI/SNRI, or severity at the end of SSRI/SNRI treatment phase. ${ }^{28}$ The second study, a 12 week RPCT, further showed positive effects of aripirazole for elderly with TRD. TRD patients older than 60 years old were randomized into two groups: venlafaxine extended-release (ER) with aripirazole or venlafaxine ER with a placebo. ${ }^{29}$ The results showed a greater proportion of the participants in the aripiprazole group achieved remission than did those in the placebo group ( $44 \%$ vs. $29 \%, \mathrm{p}<0.05$ ). However, aripiprazole augmentation was associated with more akathisia ( $24 \%$ vs. $1 \%$ ) and Parkinsonism (17\% vs. $2 \%$ ) than placebo augmentation. However, aripiprazole was not associated with an increase in cardio-metabolic risk as measured by changes in whole body adiposity, plasma lipids, glucose, or insulin.

A 6-week, randomized, rater-blinded, direct comparison study compared aripiprazole augmentation $(\mathrm{n}=52)$ and antidepressant switching $(n=49)$ in patients with MDD. ${ }^{30}$ The mean change in the MADRS score from the baseline was significantly higher in the aripiprazole augmentation group, with a difference in magnitude of $-8.7(\mathrm{p}<0.0001)$, with the intergroup difference first observed in week 2 . The numbers of responders $(60 \%$ vs. $32.6 \%, \mathrm{p}<0.01)$ and remitters ( $54 \%$ vs. $19.6 \%, \mathrm{p}<0.0001)$ were also significantly higher in the aripiprazole augmentation group compared with the switching group. The tolerability profiles were comparable between the two groups. The same research group also compared aripiprazole augmentation, antidepressant combination, and switching therapy in patients with MDD who are partial- or non-responsive to current antidepressants. ${ }^{31}$ The primary efficacy measure was the proportion of patients showing an improvement in the Clinical Global Impression-Clinical Benefit (CGI-CB) score at week 8. Among 295 patients (aripiprazole augmentation $\mathrm{N}=156$, antidepressant combination $\mathrm{N}=93$, and antidepressant switching $\mathrm{N}=46$ ), improvement was significantly greater with aripiprazole augmentation $(74.1 \%)$ than with antidepressant combinations $(48.1 \%$; $<0.001)$ and similar to with antidepressant switching $(73.5 \%$, $\mathrm{p}=0.948$ ). Tolerability profiles were similar across the three groups, but mean weight gain for the antidepressant switching group $(0.1 \mathrm{~kg})$ was significantly less than that for 
the aripiprazole augmentation group $(1.3 \mathrm{~kg}, \mathrm{p}<0.05)$.

(3) Quetiapine: Quetiapine received US FDA approval as an augmentation therapy to antidepressants for treating MDD in 2009. Unlike aripirazole, however, its clinical efficacy in MDD has been shown in numerous clinical trials involving it both as an augmentation and monotherapy. ${ }^{19}$ Until 2012, ten PRCTs ( $\mathrm{N}=4$ for monotherapy and $\mathrm{N}=6$ for augmentation therapy) investigating efficacy of quetiapine in MDD were published. ${ }^{32-41}$ In terms of monotherapy, two studies used fixed-doses and showed that quetiapine $\mathrm{XR}$ was more effective than a placebo in reducing depressive symptoms starting at week $1 .{ }^{35,42}$ Among them, one study further showed that significant reduction was seen at week 1 with quetiapine XR $150 \mathrm{mg} /$ day and $300 \mathrm{mg} /$ day versus placebo $(p<.01)$, but not with duloxetine. ${ }^{35}$ One study used flexible-dose and demonstrated superior efficacy over a placebo, ${ }^{32}$ while another study was a 52 -week, randomized-withdrawal, RPCT following a open-label stabilization phase treatment showing that the risk of depression recurrence was significantly $(\mathrm{p}<.001)$ reduced by $66 \%$ in patients randomized to continue with quetiapine $\mathrm{XR}$ versus patients randomized to switch to placebo.33 In terms of augmentation therapy, 6 quetiapine augmentation RPCTs were conducted for the treatment of MDD. ${ }^{36-41}$ Among them, one failed to show superior efficacy over placebo, but the quetiapine dosages used in study were lower than the others (flexible dose from $25-100 \mathrm{mg} /$ day, mean dose: $47 \mathrm{mg} /$ day). Interestingly, one study showed that the quetiapine plus CBT group demonstrated a significant reduction in both primary efficacy measures, compared with CBT plus placebo. ${ }^{39}$

Thereafter, 3 more RPCTs demonstrating the efficacy of quetiapine as a monotherapy in the treatment of MDD were published. Locklear et al investigated the efficacy of quetiapine XR monotherapy on the quality of life and sleep in elderly patients with MDD. ${ }^{43}$ In this 11 -week study (9-week randomized; 2-week post-treatment), MDD patients older than 66 were randomized to quetiapine XR (flexible dosing 50-300 mg/day) or placebo. The primary efficacy measures included the MADRS total score change from randomization at Week 9, the Quality of Life, Enjoyment and Satisfaction Questionnaire Short Form (Q-LES-Q-SF), and the Pittsburgh Sleep Quality Index (PSQI) global scoreto assess the quality of life and quality of sleep respectively. At Week 9, the reduction of the MADRS totals were significantly greater in quetiapine $\mathrm{XR}(\mathrm{N}=166)$ than in placebo. In addition, quetiapine XR significantly improved the Q-LES-Q-SF percentage of thetotal score (16.86; difference: 7.69; 95\% CI: 4.99, 10.39; $\mathrm{p}<0.001$ ) versus placebo (9.17). Improvement in the PSQI global score was also greater for quetiapine XR ( -6.42 ; difference: 3.52 ; 95\% CI: $4.26,2.79 ; \mathrm{p}<0.001)$ than for the placebo (2.89). McIntyre has recently published a RPCT which extended quetiapine's possible efficacy in patients having MDD with comorbid fibromyalgia syndrome. ${ }^{44}$ In this 8 week study, the mean change in the HAM-D score (primary efficacy measure) from the baseline to week 8 was significantly greater in the quetiapine XR (mean dosage $=224 \mathrm{mg} /$ day) group than in the placebo group (10.0 versus $5.8 ; \mathrm{p}=0.001$ ). Except for on the Sheehan Disability Scale (SDS), improvements in all secondary outcome scores including BPI, HAM-A, CGI, FIQ, and Q-LES-Q-SF were also greater for quetiapine than for the placebo. Overall, quetiapine XR was well tolerated in patients with a dual diagnosis of MDD and fibromyalgia. However, quetiapine was related to worsening of Triglycerides (elevation), high-density lipoprotein cholesterol levels (reduction), and weight gain than placebo, which all are consistent with the known metabolic profile for quetiapine. Among the three, only the one study by Wang failed to show superior efficacy of quetiapine XR over the placebo in the treatment of MDD. ${ }^{45}$ The study was a 10-week (8-week active treatment/2-week post-treatment) study which included 471 patients randomized to receive quetiapine $\mathrm{XR}(\mathrm{N}=157)$, escitalopram $(\mathrm{N}=157)$, or a placebo $(\mathrm{N}=157)$. The results showed that neither quetiapine XR (150/300 mg/day) nor escitalopram (10/20 mg/day) showed significant separation from the placebo, indicating that it was a failed study rather than negative study.

An interesting study which pooled data from the two 6 -week RPCTs ${ }^{36,37}$ as an augmentation therapy in the treatment of MDD was published recently. ${ }^{46}$ The study investigated the effects of psychiatric history and baseline demographics and disease characteristics on efficacy outcomes by evaluating population subgroups. The study did not find major differences between responders and non-responders with regard to psychiatric history, baseline demographics or disease characteristics. In addition, a predictive association between the number of depressive episodes, disease severity at the baseline, or baseline MADRS item scores and efficacy outcomes were not observed. The study might indicate that quetiapine XR monotherapy is effective for the treatment of MDD across a broad range of disease severities.

(4) Olanzapine: A olanzapine and fluoxetine combination agent (OFC) has only recently been approved for treating TRD. Five RPCTs (two identically designed studies were published together in one article) investigating OFC in the treatment of acute TRD have been available since 2012. ${ }^{5,47-49}$ The primary efficacy measure was the mean change in the MADRS total score from the baseline in all five OFC trials. Among them, study 1 by Thase showed no statistically significant difference in the MADRS mean change (olanzapine/fluoxetine combination: -11.0, fluoxetine: -9.4 , olanzapine: -10.5$).{ }^{49}$ The remaining four studies, including study 2 by Thase, showed that an olanzapine/fluoxetine combination produced significantly greater improvement than its comparator including olanzapine and fluoxetine monotherapy, ${ }^{5,47-49}$ nortriptyline,${ }^{47}$ or venlafaxine. ${ }^{48}$ In addition, three RPCTs (two identically designed studies were published together in one article) investigated the efficacy of OFC in treatment of MDD with psychotic features. Study 1 by Rothschild demonstrated the superiority of OFC $(-20.9)$ over placebos $(-10.4)$ in the mean change of the HAMD-24 total score from the baseline 
to the endpoint while olanzapine $(-14.9)$ did not separate from the placebo. ${ }^{50}$ However, study 2 by Rothschild did not show a significant difference among the treatment groups. ${ }^{50}$ The third study demonstrated a statistically higher remission rate for olanzapine plus sertraline (41.9\%) than for olanzapine plus placebo (23.9\%), indicating that olanzapine could be effective not only as an augmentation with fluoxetine but also with other SSRIs. ${ }^{51}$

Only one RPCT was published since January 2013. Brunner and colleagues evaluated the relapse prevention in TRD patients on OFC. ${ }^{52}$ The study included 4 phases. TRD was defined as patients who failed to show a satisfactory response to $>2$ different antidepressants for $>6$ weeks within the current MDD episode. Patients first underwent a 3-4 days screening period (Phase I) followed by a 6-8 weeks open-Label acute treatment period (Phase II) using OF. Thereafter, patients who showed response ( $>50 \%$ improvement in MADRS and $<3$ in CGI-S) received stabilization treatments for 12 weeks (Phase III). Finally, patients who were still stabilized were randomized to either an OFC or fluoxetine alone group for up to 27 weeks (Phase IV). The primary efficacy measure (relapse time) was significantly longer in OFC group than in fluoxetine alone group ( $\mathrm{p}<0.001$ ). Relapse rates were also lower for OFC vs. fluoxetine $(15.8 \%$ vs. $31.8 \%, \mathrm{p}<0.001)$. In addition, the mean total MADRS score increased from 5.36 at the baseline to 8.07 at the endpoint for OFC where as it increased from 5.40 at the baseline to 11.82 at the endpoint for fluoxetine treated patients $(p<0.001)$. In terms of safety, no significant differences between treatment groups were observed in the occurrence of SAEs $(p=0.621)$. However, the rate of patients who experienced clinically significant $(>$ $7 \%$ ) weight gain was greater for OFC than fluoxetine (OFC: $11.8 \%$, fluoxetine: $2.3 \% ; \mathrm{p}<0.001$ ). At the endpoint, the mean differences were significant for weight gain (OFC: $+1.14 \mathrm{~kg}$, fluoxetine: $-2.78 \mathrm{~kg} ; \mathrm{p}<0.001$ ). In addition, the OFC group (14.9\%) had higher prolactin values than the fluoxetine alone group $(6.3 \%)(\mathrm{p}<0.009)$.

\section{2) SGAs which have not received US FDA approval in the treatment of MDD}

(1) Amisulpride: Despite amisulpride not being approved for the treatment of MDD, its clinical usefulness for MDD or dysthymia patients as a monotherapy or augmentation therapy has been actively tested in open-label ${ }^{53,54}$ RCT studies and RPCTs. ${ }^{55-62}$ In terms of RCTs, 7 studies were conducted in the treatment of MDD or dysthymia as a monotherapy. 2 RCTs showed its superior efficacy over placebo, ${ }^{58,60}$ while all studies showed its comparable efficacy with various antidepressants including amitriptyline, amineptine, imipramine, fluoxetine, sertraline, and paroxetine. ${ }^{55-62}$ Among them, one study was designed to compare the incidences of treatment emergent adverse events between amisulpride and amitriptyline, ${ }^{57}$ which showed comparable rates of TEA (AMI vs. AMSP: 73\% vs. $64 \%$ ). However, all the above studies were published before 2006 rendering a need for updated studies. In addition, all
RCTs investigated its effects as a monotherapy.

(2) Risperidone: Similar to amisulpride, risperidone's clinical effects in the treatment of MDD has been actively investigated up until 2009. In terms of RCTs, 5 were conducted and showed its clinical effects as an augmentation therapy for the treatment of TRD. Two studies showed superior efficacy of risperidone augmentation to current antidepressants compared to placebo in response and remission among treatment resistant depression or difficult to treat depression. ${ }^{63,64}$ One study showed the efficacy of risperidone augmentation for TRD versus a placebo treatment in decrease suicidality. ${ }^{65}$ Two studies tested the efficacy of risperidone augmentation as maintenance therapy versus placebo. ${ }^{66,67}$ Both studies showed that while the relapse rates of risperidone (53.3\%-56\%) and placebo (54.6\%-65\%) were similar, the median time to relapse was numerically longer with risperidone augmentation (102-105 days) than with the placebo (57-85 days). The latest RCT, which was published in 2011, compared the efficacy of augmentation of risperidone $2 \mathrm{mg} /$ day $(\mathrm{N}=45)$, sodium valproate 600 $\mathrm{mg} /$ day $(\mathrm{N}=39)$, buspirone $30 \mathrm{mg} /$ day $(\mathrm{N}=46)$, trazodone $100 \mathrm{mg} /$ day $(\mathrm{N}=47)$ or thyroid hormone $80 \mathrm{mg} /$ day $(\mathrm{N}=48)$ in TRD patients taking paroxetine $20 \mathrm{mg} /$ day. The results showed no statistical significance among treatment groups in remission rates and AEs. However, there has only one study published since 2010 and all of the RCTs only investigated its effect as an augmentation therapy as opposed to a monotherapy.

(3) Ziprasidone: Unlike for amisulpride and risperidone, studies investigating the clinical effects in the treatment of MDD using ziprasidone have not been conducted until very recently. There was only one published RPCT for ziprasidone in the treatment of MDD as of $2012 .{ }^{68}$ One hundred and twenty (120) patients were randomized to ziprasidone monotherapy (drug-drug) for 12 weeks, placebo for 6 weeks followed by ziprasidone (placebo-drug) for 6 weeks, or placebo (placebo-placebo) for 12 weeks. The results did not show a statistically significant difference in response or remission rates among the three groups. However, the dosage of ziprasidone used might not have been sufficient to produce an antidepressant response (a daily dose of ziprasidone; phase I=81.4 mg, Phase II=113.8 mg). Relatively high pooled placebo responses and remission rates in phase II (29.9\% and $32.7 \%)$ are another possible factor preventing the detection of the statistical significance of ziprasidone over placebo.

Thereafter, 2 post-hoc analyses were recently published. Jeon et al conducted a post-hoc analysis to investigate effects of ziprasidone monotherapy in treatment of psychomotor symptoms of MDD. ${ }^{69}$ The study involved drug-drug for 12 weeks, placebo-drug for 6 weeks respectively, and placebo-placebo for 12 weeks. In phase I, more significant improvement in HDRS-17 ( $\mathrm{F}=5.95, \mathrm{p}=0.017$ ) and Quick Inventory of Depressive Symptomatology Scale, Self-Rated (QIDS-SR) $(\mathrm{F}=5.26, \mathrm{p}=0.025)$ scores were found in the ziprasidone monotherapy group than in the placebo treatment among patients presenting psychomotor symptoms, 
although there was no significant differences in the HDRS-17 $(\mathrm{F}=2.32, \mathrm{p}=0.15)$ and $\mathrm{QIDS}-\mathrm{SR}(\mathrm{F}=3.70, \mathrm{p}=0.074)$ scores between the two treatment groups among those without psychomotor symptoms. In phase II, the ziprasidone monotherapy showed no superior efficacy over placebo in HDRS-17 and QIDS-SR scores in patients with or without psychomotor symptoms. Heo et al. ${ }^{70}$ conducted another post-hoc analysis utilizing data from the study by Papakostas to investigate the effects of ziprasidone monotherapy in anxious depression. The results failed to show superior efficacy of ziprasidone over placebo in anxious depression. The second RPCT investigating augmentation of ziprasidone to antidepressants in the treatment of MDD was very recently published..$^{71}$ During an open label trial (phase I), patients with MDD were prescribed escitalopram for 8 weeks. The starting dosage of escitalopram was $10 \mathrm{mg} / \mathrm{day}$, which could be escalated to $30 \mathrm{mg} /$ day. After remaining on a stable escitalopram dosage for 4 weeks, patients were randomly assigned to a placebo group $(\mathrm{N}=68)$ or a ziprasidone augmentation group $(\mathrm{N}=71)$. Rates of clinical response were significantly higher for the adjunctive ziprasidone group $(\mathrm{N}=25$ [35.2\%]) than for the adjunctive placebo group according to the mixed-effects model with repeated-measures analyses $(\mathrm{N}=14$ [20.5\%], $\mathrm{p}=0.04)$. In addition, mean improvement in HAM-D total scores were significantly greater for ziprasidone $(-6.4)$ than for placebo $(-3.3)$ augmentation.

(4) Other SGAs: Although asenapine, iloperidone, and sertindole were not investigated for the treatment of MDD, such SGAs have been also found to exert proper and relevant pharmacodynamics including interaction with multiple neurotransmitters receptors associated with putative action mechanisms as antidepressants as presented in Table 1.

Cariprazine is a new SGA which received US FDA approval for the treatment of schizophrenia and bipolar I disorder on September $15^{\text {th }}, 2015 .^{72}$ An unpublished phase II study was conducted to investigate cariprazine's efficacy in MDD patients who have failed to respond to at least 2 antidepressant therapies. ${ }^{73}$ Two hundred thirty-two (232) patients were randomized to receive adjunctive cariprazine 0.1-0.3 mg/d, adjunctive cariprazine 1.0-2.0 mg/d, or adjunctive placebo, for 8 weeks. No significant differences among three treatment groups was found in the mean change of the MADRS from the baseline to week 8 . Another 8-week RPCT (NCT01469377) was completed, but the results are still not available. In addition, two more RPCTS (NCT01838876 and NCT01715805) investigating its efficacy in treating MDD as an augmentation agent to ADT are still ongoing.

Regarding paliperidone, only one case is still available in the treatment of TRD. ${ }^{74}$ In the case report, a 54-year-old female inpatient with depression showed symptom remission 2 weeks after $3 \mathrm{mg} /$ day of paliperidone was added to venlafaxine-XR. Full remission was maintained for 4 months with no serious adverse effects.

A recent randomized, double-blind, placebo-controlled study evaluated the efficacy and safety of lurasidone in major depressive disorders having mixed features. ${ }^{75}$ The study enrolled patients, aged 18-75, meeting DSM-IV-TR criteria for major depressive disorders who presented with two or three protocol-defined manic symptoms on most days for at least 2 weeks prior to the screening. They were randomly assigned to 6 weeks of a double-blind treatment with either lurasidone at $20-60 \mathrm{mg} /$ day $(\mathrm{N}=109)$ or placebo $(\mathrm{N}=100)$. The primary efficacy endpoint was mean change from baseline to week 6 of the MADRS total score. Lurasidone showed superior efficacy over placebo in mean change from baseline to week 6 in MADRS total score $(-20.5$ vs. $-13.0 ; p$ $<0.001$; effect size of 0.80). In terms of safety, nausea, somnolence, dizziness, akathisia, abdominal discomfort, dry mouth, and Parkinsonism were observed more frequently with lurasidone than with the placebo. The rate of discontinuation due to adverse events was $2.8 \%$ in the lurasidone group and $5.0 \%$ in the placebo group. It was the first placebo-controlled clinical trial that included patients with major depressive disorders associated with subthreshold hypomanic symptoms (mixed features). Depressive disorders presenting with mixed features are known to have complex courses and be associated with significant morbidity, so the study has both clinical and research significance.

A summary of RPCTs of SGAs published after our previous review article other than Brexipraxole is presented in Table 3.

\section{DISCUSSION}

Increasing evidence has shown that SGAs may provide some benefits for the treatment of MDD (TRD) as either an augmentation or monotherapy. Accordingly, aripiprazole was the first SGA to receive FDA approval as an augmentation agent for the treatment of MDD followed by quetiapine $\mathrm{XR}$ and the combined agent of olanzapine plus fluoxetine (Symbiax). Recently, brexpiprazole, a newly developed SGA, was added to the above list by receiving FDA approval in July 2015 for the treatment of MDD as an augmentation to ADT. Besides of numerous post-hoc and open label studies, 8 RPCTs (aripiprazole $=2$, quetiapine $=3$, olanzapine $=1$, ziprasidone $=1$, and lurasidone $=1$ ) have been published since January 2013 illustrating that mounting evidence in utility of diverse SGAs in treating MDD.

In our previous review, we commented that there are a number of issues that need to be addressed despite considerable evidence supporting SGAs' viable role as augmentation agents for the treatment of MDD or TRD. ${ }^{14}$ On the other hand, many issues have already been addressed in the past decade, which are illustrated in the 8 meta-analyses of SGA in the treatment of MDD published so far (Table 4).

Even before aripiprazole was approved for MDD, off-label use of SGAs for MDD were not uncommon, especially in TRD. ${ }^{76}$ In light of the increasing off-label use of diverse SGAs for the treatment of TRD, the initial concern in mid-2000s was whether SGAs were truly safe and effective 
TABLE 3. Randomized, double-blind, placebo-controlled trials of SGAs in major depressive disorder since 2013

\begin{tabular}{|c|c|c|c|c|c|}
\hline Study (year) & Duration & Design & Patients (n) & Primary end point & Other results \\
\hline \multicolumn{6}{|l|}{ Aripiprazole } \\
\hline $\begin{array}{l}\text { Lenze et al } \\
(2015)^{29}\end{array}$ & 12 weeks & $\begin{array}{l}\text { Aug, age } \\
>60 \text { year }\end{array}$ & $\begin{array}{l}\text { VFX+ARP (91) } \\
\text { VFX+PBO (90) }\end{array}$ & $\begin{array}{l}\text { Remission by MADRS } \\
\text { PBO: } 29 \% \text {; ARP: } 44 \%^{\text {a }}\end{array}$ & $\begin{array}{l}\text { Secondary measure: } \\
\mathrm{NNT}=6.6\end{array}$ \\
\hline $\begin{array}{l}\text { Kamijima } \\
(2013)^{27}\end{array}$ & 14 weeks & Aug & $\begin{array}{l}\text { ADT+PBO (195) } \\
\text { ADT+ARP Fix (194) } \\
\text { ADT+ARP Flex (197) }\end{array}$ & $\begin{array}{l}\text { Changes in MADRS } \\
\text { PBO: }-7.4 \text {; ARP Fix: }-10.5^{\mathrm{a}} \text {; } \\
\text { ARP Flex: }-9.6^{\mathrm{a}}\end{array}$ & $\begin{array}{l}\text { Response: Flex }(39.2 \%)^{\mathrm{a}}, \\
\text { Fix }(42.1 \%)^{\mathrm{a}}, \text { PBO }(28.2 \%) / \\
\text { Remission: Flex }(30.4 \%)^{\mathrm{a}}, \\
\text { Fix }(32.5 \%)^{\mathrm{a}}, \text { PBO }(20.5 \%)\end{array}$ \\
\hline \multicolumn{6}{|l|}{ Quetiapine } \\
\hline $\begin{array}{l}\text { Locklear et al } \\
(2013)^{43}\end{array}$ & 11 weeks & Mono, age $>66$ & $\begin{array}{l}\text { QTP XR flex (166) } \\
\text { PBO (172) }\end{array}$ & $\begin{array}{l}\text { Changes in MADRS } \\
\text { PBO: }-8.79 \text {; QTP: }-16.33^{\mathrm{a}}\end{array}$ & $\begin{array}{l}\text { Q-LES-Q-SF \% improvement } \\
\text { PBO: } 9.17 \text {; QTP: } 16.86^{\mathrm{a}}\end{array}$ \\
\hline $\begin{array}{l}\text { McIntyre et al } \\
\quad(2014)^{44}\end{array}$ & 8 weeks & $\begin{array}{l}\text { Mono, FM with } \\
\text { MDD }\end{array}$ & $\begin{array}{l}\text { QTP XR flex (61) } \\
\text { PBO (59) }\end{array}$ & $\begin{array}{l}\text { Change in HAM-D } \\
\text { PBO: }-5.8 \text {; QTP: }-10.0^{\mathrm{a}}\end{array}$ & $\begin{array}{l}\text { BPI, HAM-A, CGI, FIQ, } \\
\text { Q-LES-Q-SF improved } \\
\text { greater in QTP than in PBO }\end{array}$ \\
\hline $\begin{array}{l}\text { Wang et al } \\
\qquad(2014)^{45}\end{array}$ & 10 weeks & Mono & $\begin{array}{l}\text { QTP XR (157) } \\
\text { EPAM (157) } \\
\text { PBO (157) }\end{array}$ & $\begin{array}{l}\text { Changes in MADRS } \\
\text { (QTP: }-19.5 \text {; EPAM: }-19.8 \text {; } \\
\text { EPAM: -18.3) }\end{array}$ & $\begin{array}{l}\text { Response and remission: } \\
\text { no significant difference } \\
\text { among groups }\end{array}$ \\
\hline \multicolumn{6}{|l|}{ Olanzapine } \\
\hline $\begin{array}{l}\text { Brunner et al } \\
(2014)^{52}\end{array}$ & 27 weeks & $\begin{array}{l}\text { With FOX in } \\
\text { TRD }\end{array}$ & $\begin{array}{l}\text { OF }(221) \\
\text { FOX }(223)\end{array}$ & $\begin{array}{l}\text { Time-to-relapse } \\
\text { OZA/FOX }{ }^{\mathrm{a}} \text { longer than FOX }\end{array}$ & $\begin{array}{l}\text { MADRS increase from } \\
\text { baseline to endpoint } \\
\text { OF: } 5.36 \text { to } 8.07^{\mathrm{a}} \\
\text { FOX: } 5.40 \text { to } 11.82\end{array}$ \\
\hline \multicolumn{6}{|l|}{ Ziprasidone } \\
\hline $\begin{array}{l}\text { Papakostas et al } \\
(2015)^{68}\end{array}$ & 8 weeks & Aug & $\begin{array}{l}\text { EPAM+ZIP: } 71 \\
\text { EPAM+PBO: } 68\end{array}$ & $\begin{array}{l}\text { Response by HAMD-D } \\
\text { EPAM+ZIP: } 35.2 \%^{\mathrm{a}} \\
\text { EPAM+PBO: } 20.5 \%\end{array}$ & $\begin{array}{l}\text { HAM-D total scores } \\
\text { improvement } \\
\text { EPAM+ZIP:-6.4 } \\
\text { EPAM+PBO: }-3.2\end{array}$ \\
\hline \multicolumn{6}{|l|}{ Lurasidone } \\
\hline $\begin{array}{l}\text { Suppes et al } \\
(2015)^{75}\end{array}$ & 6 weeks & $\begin{array}{l}\text { Mono, MDD with } \\
\text { mixed features }\end{array}$ & $\begin{array}{l}\text { LSD (109) } \\
\text { PBO (100) }\end{array}$ & $\begin{array}{l}\text { Changes in MADRS } \\
\text { LSD: }-20.5^{\mathrm{a}} \text { PBO: }-13.0\end{array}$ & $\begin{array}{l}\text { Response: LSD }(64 \%), \\
\text { PBO }(30.0 \%)^{\mathrm{a}} \\
\text { Remission: LSD }(49.1 \%), \\
\text { PBO }(23.0 \%)^{\mathrm{a}}\end{array}$ \\
\hline
\end{tabular}

${ }_{\mathrm{a}}^{\mathrm{a}}<0.05$ vs placebo, otherwise not significant.

ARP: aripiprazole, Aug: augmentation, BPI: brief pain inventory short form, EPAM: escitalopram, FIQ: fibromyalgia impact questionnaire, Fix: fixed dosing, Flex: flexible dosing, FM: fibromyalgia, FOX: fluoxetine, GAS: global assessment scale, HAMD-D: 17-item hamilton depression rating scale, LSD: lurasidone, MADRS: montgomery-asberg depression rating scale, Mono: monotherapy, NNT: number needed to treat, OF: olanzapine and fluoxetine combination, PBO: placebo, PHQ: patient health questionnaire, Q-LES-Q-SF: quality of life enjoyment and satisfaction questionnaire short form, QTP: quetiapine, XR: extended release, ZIP: ziprasidone.

for TRD. Thus, the first meta-analysis was conducted by Papakostas to address these two important concerns. ${ }^{77}$ The study included 10 RPCTs involving more than 1500 outpatients with TRD, which showed that SGA augmentation (olanzapine, risperidone, and quetiapine) yielded greater clinical remission/response than placebo augmentation. However, the rate of discontinuation due to adverse events was lower for placebo than for SGA augmentation treated patients $(R R=3.38$, CI-1.98to5.76, $p<0.0001)$, so the safety issue surrounding SGA augmentation became the concern since the first meta-analysis. In the second meta-analysis, which was published in 2009, 6 more RPCTs were added and the SGAs included were broadened to include aripiprazole. ${ }^{78}$ In line with the first meta-analysis, the results showed that SGAs were effective as augmentation agents for MDD but are associated with an increased risk of discontinuation due to adverse events. ${ }^{79}$
With an increasing number of RPCTs being published, subsequent meta-analysis investigated the efficacy of specific SGAs (aripiprazole or quetiapine) rather than diverse SGAs as a whole. ${ }^{80,81}$ The study by Arbaizar contained 4 RPCTs (2 RPCTs for TRD and 2 RPCTs for bipolar depression), and it showed that aripiprazole is effective for increasing response rates in depressive patients. In terms of safety, akathisia was more frequently reported in patients taking aripiprazole than in patients taking the placebo. Similarly, a meta-analysis containing 3 RPCTs showed that the response rate of the quetiapine XR-treated group was significantly greater than that of the placebo-treated group. ${ }^{81}$ Although the overall discontinuation rate of quetiapine XR was not significantly higher than that of the placebo's, the discontinuation rate due to adverse events was higher in the quetiapine XR group than in the placebo group. 
TABLE 4. Meta-analysis investigating second genration antipsychotics in the treatment of MDD

\begin{tabular}{|c|c|c|c|c|c|}
\hline Study & RCTs & Patients & SGAs included & Design & Results \\
\hline Papakostas $(2007)^{77}$ & 10 & 1,500 with TRD & $\begin{array}{l}\text { OZP:5 / RIP: } 2 \\
\text { QTP:3 }\end{array}$ & Aug & $\begin{array}{l}\text { SGA }>\text { PBO in remission }([R R]=1.75, p<.0001) \text { or clinical re- } \\
\text { sponse }(R R=1.35, p=.001)\end{array}$ \\
\hline Nelson $(2009)^{78}$ & 16 & 3,480 & $\begin{array}{l}\text { OZP:5 / RIP: } 3 \\
\text { QTP:5 / ARP:3 }\end{array}$ & Aug & $\begin{array}{l}\text { SGA }>\text { PBO in response }([\mathrm{OR}]=1.69, \mathrm{p}<.00001) \text { or remission } \\
(\mathrm{OR}=2.00, \mathrm{p}<.00001) . \text { Discontinuation due to adverse } \\
\text { events } \mathrm{SGA}>\mathrm{PBO}([\mathrm{OR}]=3.91, \mathrm{p}<0.00001)\end{array}$ \\
\hline Arbaizar $(2009)^{80}$ & 4 & 1,488 & ARP only & Mono & $\begin{array}{l}\mathrm{ARP}>\mathrm{PBO} \text { in response }(\mathrm{ARP}-\mathrm{PBO}=7.7 \%, 95 \% \mathrm{CI}: 1.5-14.2) \\
\mathrm{ARP}>\mathrm{POB} \text { in akathisia }(\mathrm{ARP}-\mathrm{PBO}=20.3 \%, 95 \% \mathrm{CI} \\
16.9-23.7)\end{array}$ \\
\hline Maneeton $(2012)^{81}$ & 3 & 1,497 & QTP & Mono & $\begin{array}{l}\mathrm{QTP}>\mathrm{PBO} \text { in response }([\mathrm{RR}]=1.44,95 \% \mathrm{CI}: 1.26-1.64) \text { or } \\
\text { in remission response }([\mathrm{RR}]=1.37,95 \% \mathrm{CI}: 1.12-1.68) \text {. } \\
\text { Discontinuation due to adverse events QTP }>\text { PBO }([\mathrm{RR}]= \\
2.90,95 \% \mathrm{CI}: 1.87-4.48)\end{array}$ \\
\hline Spielmans $(2013)^{82}$ & 14 & 3,549 & $\begin{array}{l}\text { OZP:5 / RIP: } 3 \\
\text { QTP:3 / ARP:3 }\end{array}$ & Aug & $\begin{array}{l}\text { All four drugs had statistically significant effects on remission. } \\
\text { The number needed to treat (NNT) was } 19 \text { for OFC and nine } \\
\text { for other } 3\end{array}$ \\
\hline Wen $(2014)^{83}$ & 17 & 3,807 & $\begin{array}{l}\text { OZP:5 / RIP: } 3 \\
\text { QTP:5 / ARP:5 }\end{array}$ & Aug & $\begin{array}{l}\text { SGA }>\text { PBO in response }([R R]=1.68, p<.00001) \text { or remission } \\
([R R]=1.90, p<.00001) . \text { Discontinuation due to adverse } \\
\text { events SGA }>\text { PBO }([R R]=3.32, p<.00001)\end{array}$ \\
\hline Zhou $(2015)^{85}$ & 48 & 6,654 & $\begin{array}{l}\text { OZP:4 / RIP: } 3 \\
\text { QTP:6 / ARP:4 }\end{array}$ & Aug & $\begin{array}{l}\text { QTP, ARP, thyroid hormone, and lithium }>\text { PBO in response } \\
\text { QTP, ARP }>\text { thyroid hormone and lithium in response }\end{array}$ \\
\hline Zhou $(2015)^{86}$ & 18 & 4,422 with TRD & $\begin{array}{l}\text { OZP:5 / RIP: } 3 \\
\text { QTP:5 / ARP:5 }\end{array}$ & Aug & $\begin{array}{l}\text { All standard dose SGA }>\text { PBO in efficacy (the mean change } \\
\text { score of depression rating scales from baseline to endpoint), } \\
\text { but low dose SGA=PBO in efficacy } \\
\text { Discontinuation due to adverse events standard dose SGA } \\
\text { (except for RIP) }>\text { PBO ([OR]=2.72-6.40) }\end{array}$ \\
\hline Wang $(2015)^{87}$ & 11 & 3,341 with TRD & $\begin{array}{l}\text { OZP:2 / RIP: } 1 \\
\text { QTP:3 / ARP:5 }\end{array}$ & Aug & $\begin{array}{l}\mathrm{SGA}>\mathrm{AD} \text { monotherapy in response }([\mathrm{RR}]=1.38,95 \% \mathrm{CI} \text { : } \\
1.25-1.53) \text { or remission }([\mathrm{RR}]=1.62,95 \% \mathrm{CI}: 1.42-1.85) \\
\text { Response rate of SGA differed according to the degree of TRD } \\
(\mathrm{TRD} 1: \mathrm{RR}=1.24 \text {; TRD } 2: \mathrm{RR}=1.37 \text {; TRD } 2-4: \mathrm{RR}=1.58) \text {. } \\
\text { SGA=AD monotherapy in remission for non-TRD trials }\end{array}$ \\
\hline
\end{tabular}

AD: antidepressant, ARP: aripiprazole, Aug: augmentation trial, Mono: monotherapy trial, OR: odds ratio, OZP: olanzapine, PBO: placebo, Pfs-MDD: MDD with psychotic features, RIP: risperidone, RR: relative ratio, QTP: quetiapine, SGA: second generation antipsychotics, TRD: treatment resistant depression.

The meta-analyses by Papakostas et al. ${ }^{77}$ and Nelson Papakostas ${ }^{78}$ analyzed efficacy only in terms of dichotomous response and remission outcomes using clinician-rated depression measures, and safety was only assessed using the discontinuation due to adverse events. Spielmans et al.$^{82}$ tried to fulfill this gap by conducting a meta-analysis to provide a comprehensive estimate of the efficacy and safety profiles including functional status, quality of life, and drug-related side effects. The study included 14 RPCTs containing four SGAs (aripiprazole, olanzapine, quetiapine, and risperidone). With regard to efficacy, all four drugs had statistically significant effects on remission with a NNT of 19 for olanzapine and a NNT of 9 for other SGAs. In terms of response, aripiprazole $(\mathrm{NNT}=7)$, quetiapine $(\mathrm{NNT}=10)$ and risperidone $(\mathrm{NNT}=8)$ showed higher remission rates than of the placebo, but $\mathrm{OF}$ combinations did not (NNT=19). In terms of quality of life and functioning, only risperidone was more efficacious than adjunctive placebo with a small-to-moderate effect size, but its effect should be should be interpreted cautiously because it is largely driven by post hoc analyses. The study also investigated SGAs' safety in detail. With the exception of adjunctive risperidone, which was not associated with an increased rate of any spontaneously reported adverse events, the other 3 showed associations with various safety profile concerns. Adjunctive aripiprazole had a very high rate of akathisia $(\mathrm{NNH}=4)$ and was also linked to sedation $(\mathrm{NNH}=14)$, whereas $\mathrm{OF}$ combination led to a higher risk of weight gain of $\geq 10 \%$ ( $\mathrm{NNH}=9$ ), sedation $(\mathrm{NNH}=5)$, abnormal metabolic laboratory results $(\mathrm{NNH}=10)$, and elevated prolactin $(\mathrm{NNH}=6)$. Adjunctive quetiapine was highly associated with sedation $(\mathrm{NNH}=3)$ and metabolic laboratory results $(\mathrm{NNH}=6)$ and was associated with significant weight gain of $\geq 7 \%$ (NNH=37). Wen et al repeated and extended the above 3 studies by comparing long-term and short-term outcomes among patients treated with SGAs and also examined whether the response rates to SGAs would be affected by sedative drugs (lorazepam, benzodiazepine and hypnotics). ${ }^{83}$ In line with the previous research, the study showed that SGA augmentation yielded higher response and remission, but had a higher discontinuation rate due to adverse effects than the placebo. 
In addition, the study showed that short-term (4-week duration) treatment subgroup did not have a statistically greater effect than the placebo $(\mathrm{OR}=1.70 \quad[95 \% \mathrm{CI}=$ $0.98-2.95])$, whereas the long-term $(6-, 8-, 12$-week duration) treatment subgroups $\operatorname{did}(\mathrm{OR}=1.68$ [95\%CI=1.45-1.94], $\mathrm{p}<.00001)$.

Traditional meta-analysis usually cannot answer a comparative effectiveness question across multiple treatments, especially when there are limited head-to-head trials. ${ }^{84}$ Zhou et al. ${ }^{85}$ sought to investigate this important issue using network meta-analysis. The study compared 11 augmentation therapies with each other and with a placebo in TRD. The 11 augmentation therapies included buspirone, lithium, methylphenidate, bupropion, thyroid hormone, lamotrigine, pindolol, and 4 SGAs (risperidone, aripiprazole, quetiapine, and olanzapine). The results showed that quetiapine (OR=1.92; 95\% CI, 1.39-3.13), aripiprazole $(\mathrm{OR}=1.85 ; 95 \% \mathrm{CI}, 1.27-2.27)$, thyroid hormone (OR=1.84; 95\% CI, 1.06-3.56), and lithium (OR=1.56; 95\% CI, 1.05-2.55) were significantly more effective than the placebo in terms of response rate, and this efficacy was more robust for quetiapine and aripiprazole than for thyroid hormone or lithium. In terms of tolerability, quetiapine, olanzapine, aripiprazole, and lithium were significantly less well tolerated than the placebo. Zhou et al conducted another network meta-analysis to compare efficacy and tolerability of adjunctive SGAs for TRD. ${ }^{86}$ The primary outcome measure was the mean change of scores of depression rating scales from the baseline to the endpoint (depression severity). The results showed that all 4 standard-dose-SGAs were significantly more efficacious than the placebo in decreasing depression severity, and no significant difference existed among 4 SGAs. In addition, all SGAs except for risperidone showed a higher discontinuation rate due to adverse effects than the placebo.

The latest meta-analysis sought to investigate which depression subgroups would be good candidates for SGA augmentation. ${ }^{87}$ The study suggested that the effect size of SGA augmentation needs to became larger as the degree of treatment resistance to ADT became higher. In contrast, SGAs failed to show superior efficacy over antidepressant monotherapies in terms of remission rates for non-TRD trials.

In addition, while SGAs may have some potential benefits in the treatment of MDD with comorbid conditions, there have only been a handful of trials. For instance, the effects of quetiapine XR was recently shown in an 8-week RPCT in patients with MDD comorbid with fibromyalgia. ${ }^{44}$ All measures of depressive symptoms, pain, and quality of life were more significantly improved in the quetiapine XR group than in the placebo group. In particular, the improvement of depressive symptoms was almost double in the quetiapine XR group compared to the placebo group. The promising effects of quetiapine for treating comorbid somatic symptoms in MDD patients were also demonstrated in a previous 6-week small scale RPCT. ${ }^{88}$ In the study, patients were assigned to either citalopram $40 \mathrm{mg} / \mathrm{d}$ plus placebo
( $\mathrm{N}=20)$ or citalopram $40 \mathrm{mg} / \mathrm{d}$ plus quetiapine (300-600 $\mathrm{mg} / \mathrm{d}, \mathrm{N}=21$ ). The mean change of the HAMD total score was the primary efficacy measure. The mean changes in the HAMD scores from the baseline to the endpoint were numerically higher in the citalopram plus quetiapine group $(-12.3)$ than in the citalopram plus placebo group $(-10.7)$. However, remission rates were significant higher in the citalopram plus quetiapine group $(41.1 \%)$ than in the citalopram plus placebo group (26.3\%). As stated above, SGAs may have some potential benefits in the treatment of MDD with comorbid medical conditions; however, large-scale RPCTs with existing various SGAs as an augmentation therapy for MDD with physical disorders or somatic symptoms are necessary to confirm their role in this aspect.

Diverse issues regarding the use of SGAs in the treatment of MDD have been addressed within past 2 decades. However, issues surrounding the optimal intervention time, specific patient population for SGA augmentation therapy, treatment duration, clinical predictors to treatment response and AEs, usefulness on special populations of interest, long-term treatment issues, best-matched antidepressants, dosing guides, and pharmacoeconomics are yet to be resolved. Above all, the currently available evidence only indicates that clinicians have to carefully pay attention to evaluation of practical and individual risks and benefits at the time of the decision to prescribe an SGA augmentation therapy.

\section{ACKNOWLEDGEMENTS}

This research was supported by a grant of the Korea Health Technology R\&D Project through the Korea Health Industry Development Institute (KHIDI), funded by the Ministry of Health \& Welfare, Republic of Korea (grant number : HC15C140).

\section{CONFLICT OF INTEREST STATEMENT}

None declared.

\section{REFERENCES}

1. Pae CU, Tharwani H, Marks DM, Masand PS, Patkar AA. Atypical depression: a comprehensive review. CNS Drugs 2009;23:1023-37.

2. Kulkarni SK, Dhir A. Current investigational drugs for major depression. Expert Opin Investig Drugs 2009;18:767-88.

3. Rush AJ, Trivedi MH, Wisniewski SR, Nierenberg AA, Stewart JW, Warden D, et al. Acute and longer-term outcomes in depressed outpatients requiring one or several treatment steps: a STAR*D report. Am J Psychiatry 2006;163:1905-17.

4. Wang SM, Han C, Pae CU. Criticisms of drugs in early development for the treatment of depression: what can be improved? Expert Opin Investig Drugs 2015;24:445-53.

5. Shelton RC, Tollefson GD, Tohen M, Stahl S, Gannon KS, Jacobs TG, et al. A novel augmentation strategy for treating resistant 
major depression. Am J Psychiatry 2001;158:131-4.

6. Masand PS, Pae CU, Krulewicz S, Peindl K, Mannelli P, Varia IM, et al. A double-blind, randomized, placebo-controlled trial of paroxetine controlled-release in irritable bowel syndrome. Psychosomatics 2009;50:78-86.

7. Kang HJ, Bae KY, Kim SW, Shin IS, Hong YJ, Ahn Y, et al. Associations between serotonergic genes and escitalopram treatment responses in patients with depressive disorder and acute coronary syndrome: The EsDEPACS study. Psychiatry Investig 2016;13:157-60.

8. Jeon SW, Han C, Lee J, Lim J, Jeong HG, Park MH, et al. Perspectives on the happiness of community-dwelling elderly in Korea. Psychiatry Investig 2016;13:50-7.

9. Park YM. Relationship between serotonergic dysfunction based on loudness dependence of auditory-evoked potentials and suicide in patients with major depressive disorder. Psychiatry Investig 2015;12:421-4

10. Gao L, Gao Y, Xu E, Xie J. Microarray Analysis of the major depressive disorder mRNA profile data. Psychiatry Investig 2015;12:388-96.

11. Lee J, Joo EJ, Lim HJ, Park JM, Lee KY, Park A, et al. Proteomic analysis of serum from patients with major depressive disorder to compare their depressive and remission statuses. Psychiatry Investig 2015;12:249-59.

12. Khosravi M, Sotoudeh G, Majdzadeh R, Nejati S, Darabi S, Raisi $\mathrm{F}$, et al. Healthy and unhealthy dietary patterns are related to depression: a case-control study. Psychiatry Investig 2015;12:434-42.

13. Ostroff RB, Nelson JC. Risperidone augmentation of selective serotonin reuptake inhibitors in major depression. J Clin Psychiatry 1999;60:256-9.

14. Han C, Wang SM, Kato M, Lee SJ, Patkar AA, Masand PS, et al. Second-generation antipsychotics in the treatment of major depressive disorder: current evidence. Expert Rev Neurother 2013;13:851-70.

15. U.S. FDA Approves Otsuka and Lundbeck's REXULTI $\AA$ (Brexpiprazole) as Adjunctive Treatment for Adults with Major Depressive Disor [Internet]. Rockville: Otsuka America Pharmaceutical, Inc.; c2016 [cited 2016 Mar 1]. Available from: http://www.otsuka-us.com/newsroom/Pages/NewsArticle.aspx? ItemId=13/.

16. Maeda K, Lerdrup L, Sugino H, Akazawa H, Amada N, McQuade $\mathrm{RD}$, et al. Brexpiprazole II: antipsychotic-like and procognitive effects of a novel serotonin-dopamine activity modulator. J Pharmacol Exp Ther 2014;350:605-14.

17. Thase ME, Youakim JM, Skuban A, Hobart M, Zhang P, McQuade $\mathrm{RD}$, et al. Adjunctive brexpiprazole 1 and $3 \mathrm{mg}$ for patients with major depressive disorder following inadequate response to antidepressants: a phase 3, randomized, double-blind study. J Clin Psychiatry 2015;76:1232-40.

18. Thase ME, Youakim JM, Skuban A, Hobart M, Augustine C, Zhang $\mathrm{P}$, et al. Efficacy and safety of adjunctive brexpiprazole 2 mg in major depressive disorder: a phase 3 , randomized, placebo-controlled study in patients with inadequate response to antidepressants. J Clin Psychiatry 2015;76:1224-31.

19. Pae CU, Sohi MS, Seo HJ, Serretti A, Patkar AA, Steffens DC, et al. Quetiapine XR: current status for the treatment of major depressive disorder. Prog Neuropsychopharmacol Biol Psychiatry
2010;34:1165-73.

20. Berman RM, Fava M, Thase ME, Trivedi MH, Swanink R, McQuade RD, et al. Aripiprazole augmentation in major depressive disorder: a double-blind, placebo-controlled study in patients with inadequate response to antidepressants. CNS Spectr 2009;14:197-206.

21. Berman RM, Marcus RN, Swanink R, McQuade RD, Carson WH, Corey-Lisle PK, et al. The efficacy and safety of aripiprazole as adjunctive therapy in major depressive disorder: a multicenter, randomized, double-blind, placebo-controlled study. J Clin Psychiatry 2007;68:843-53.

22. Marcus RN, McQuade RD, Carson WH, Hennicken D, Fava M, Simon JS, et al. The efficacy and safety of aripiprazole as adjunctive therapy in major depressive disorder: a second multicenter, randomized, double-blind, placebo-controlled study. J Clin Psychopharmacol 2008;28:156-65.

23. Casey DE, Laubmeier KK, Eudicone JM, Marcus R, Berman RM, Rahman Z, et al. Response and remission rates with adjunctive aripiprazole in patients with major depressive disorder who exhibit minimal or no improvement on antidepressant monotherapy. Int J Clin Pract 2014;68:1301-8.

24. Stewart TD, Hatch A, Largay K, Sheehan JJ, Marler SV, Berman RM, et al. Effect of symptom severity on efficacy and safety of aripiprazole adjunctive to antidepressant monotherapy in major depressive disorder: a pooled analysis. J Affect Disord 2014;162:20-5.

25. Nelson JC, Rahman Z, Laubmeier KK, Eudicone JM, McQuade $\mathrm{RD}$, Berman RM, et al. Efficacy of adjunctive aripiprazole in patients with major depressive disorder whose symptoms worsened with antidepressant monotherapy. CNS Spectr 2014;19:528-34.

26. Han C, Wang SM, Lee SJ, Jun TY, Pae CU. Optimizing the use of aripiprazole augmentation in the treatment of major depressive disorder: from clinical trials to clinical practice. Chonnam Med J 2015;51:66-80.

27. Kamijima K, Higuchi T, Ishigooka J, Ohmori T, Ozaki N, Kanba $\mathrm{S}$, et al. Aripiprazole augmentation to antidepressant therapy in Japanese patients with major depressive disorder: a randomized, double-blind, placebo-controlled study (ADMIRE study). J Affect Disord 2013;151:899-905.

28. Ozaki N, Otsubo T, Kato M, Higuchi T, Ono H, Kamijima K. Efficacy of aripiprazole augmentation in Japanese patients with major depressive disorder: a subgroup analysis and Montgomery-Åsberg Depression Rating Scale and Hamilton Rating Scale for Depression item analyses of theAripiprazole Depression Multicenter Efficacy study. Psychiatry Clin Neurosci 2015;69:34-42.

29. Lenze EJ, Mulsant BH, Blumberger DM, Karp JF, Newcomer JW, Anderson SJ, et al. Efficacy, safety, and tolerability of augmentation pharmacotherapy with aripiprazole for treatment-resistant depression in late life: a randomised, double-blind, placebo-controlled trial. Lancet 2015;386:2404-12.

30. Han C, Wang SM, Kwak KP, Won WY, Lee H, Chang CM, et al. Aripiprazole augmentation versus antidepressant switching for patients with major depressive disorder: a 6-week, randomized, rater-blinded, prospective study. J Psychiatr Res 2015;66-67:84-94.

31. Han C, Wang SM, Seo HJ, Lee BC, Jeon HJ, Kim W, et al. Aripiprazole augmentation, antidepressant combination or switching therapy in patients with major depressive disorder who are partial- or non-responsive to current antidepressants: a mul- 
ti-center, naturalistic study. J Psychiatr Res 2014;49:75-82.

32. Bortnick B, El-Khalili N, Banov M, Adson D, Datto C, Raines S, et al. Efficacy and tolerability of extended release quetiapine fumarate (quetiapine XR) monotherapy in major depressive disorder: a placebo-controlled, randomized study. J Affect Disord 2011;128:83-94.

33. Liebowitz M, Lam RW, Lepola U, Datto C, Sweitzer D, Eriksson H. Efficacy and tolerability of extended release quetiapine fumarate monotherapy as maintenance treatment of major depressive disorder: a randomized, placebo-controlled trial. Depress Anxiety 2010;27:964-76.

34. Weisler RH, Montgomery SA, Earley WR, Szamosi J, Lazarus A. Efficacy of extended release quetiapine fumarate monotherapy in patients with major depressive disorder: a pooled analysis of two 6-week, double-blind, placebo-controlled studies. Int Clin Psychopharmacol 2012;27:27-39.

35. Cutler AJ, Montgomery SA, Feifel D, Lazarus A, Aström M, Brecher M. Extended release quetiapine fumarate monotherapy in major depressive disorder: a placebo- and duloxetine-controlled study. J Clin Psychiatry 2009;70:526-39.

36. El-Khalili N, Joyce M, Atkinson S, Buynak RJ, Datto C, Lindgren $\mathrm{P}$, et al. Extended-release quetiapine fumarate (quetiapine $\mathrm{XR}$ ) as adjunctive therapy in major depressive disorder (MDD) in patients with an inadequate response to ongoing antidepressant treatment: a multicentre, randomized, double-blind, placebo-controlled study. Int J Neuropsychopharmacol 2010;13:917-32.

37. Bauer M, Pretorius HW, Constant EL, Earley WR, Szamosi J, Brecher M. Extended-release quetiapine as adjunct to an antidepressant in patients with major depressive disorder: results of a randomized, placebo-controlled, double-blind study. J Clin Psychiatry 2009;70:540-9.

38. Garakani A, Martinez JM, Marcus S, Weaver J, Rickels K, Fava $\mathrm{M}$, et al. A randomized, double-blind, and placebo-controlled trial of quetiapine augmentation of fluoxetine in major depressive disorder. Int Clin Psychopharmacol 2008;23:269-75.

39. Chaput Y, Magnan A, Gendron A. The co-administration of quetiapine or placebo to cognitive-behavior therapy in treatment refractory depression: a preliminary trial. BMC Psychiatry 2008;8:73.

40. McIntyre A, Gendron A, McIntyre A. Quetiapine adjunct to selective serotonin reuptake inhibitors or venlafaxine in patients with major depression, comorbid anxiety, and residual depressive symptoms: a randomized, placebo-controlled pilot study. Depress Anxiety 2007;24:487-94.

41. Wijkstra J, Burger H, van den Broek WW, Birkenhäger TK, Janzing JG, Boks MP, et al. Treatment of unipolar psychotic depression: a randomized, double-blind study comparing imipramine, venlafaxine, and venlafaxine plus quetiapine. Acta Psychiatr Scand 2010;121:190-200.

42. Weisler R, Joyce M, McGill L, Lazarus A, Szamosi J, Eriksson H. Extended release quetiapine fumarate monotherapy for major depressive disorder: results of a double-blind, randomized, placebo-controlled study. CNS Spectr 2009;14:299-313.

43. Locklear JC, Svedsäter H, Datto C, Endicott J. Effects of once-daily extended release quetiapine fumarate (quetiapine XR) on quality of life and sleep in elderly patients with major depressive disorder. J Affect Disord 2013;149:189-95.
44. McIntyre A, Paisley D, Kouassi E, Gendron A. Quetiapine fumarate extended-release for the treatment of major depression with comorbid fibromyalgia syndrome: a double-blind, randomized, placebo-controlled study. Arthritis Rheumatol 2014;66:451-61.

45. Wang G, McIntyre A, Earley WR, Raines SR, Eriksson H. A randomized, double-blind study of the efficacy and tolerability of extended-release quetiapine fumarate (quetiapine XR) monotherapy in patients with major depressive disorder. Neuropsychiatr Dis Treat 2014;10:201-16.

46. Bauer M, Thase ME, Liu S, Earley W, Eriksson H. Analysis of potentially predictive factors of efficacy of adjunct extended-release quetiapine fumarate in patients with major depressive disorder. J Psychopharmacol 2015;29:565-74.

47. Shelton RC, Williamson DJ, Corya SA, Sanger TM, Van Campen LE, Case M, et al. Olanzapine/fluoxetine combination for treatment-resistant depression: a controlled study of SSRI and nortriptyline resistance. J Clin Psychiatry 2005;66:1289-97.

48. Corya SA, Williamson D, Sanger TM, Briggs SD, Case M, Tollefson G. A randomized, double-blind comparison of olanzapine/fluoxetine combination, olanzapine, fluoxetine, and venlafaxine in treatment-resistant depression. Depress Anxiety 2006;23:364-72.

49. Thase ME, Corya SA, Osuntokun O, Case M, Henley DB, Sanger TM, et al. A randomized, double-blind comparison of olanzapine/fluoxetine combination, olanzapine, and fluoxetine in treatment-resistant major depressive disorder. J Clin Psychiatry 2007;68:224-36.

50. Rothschild AJ, Williamson DJ, Tohen MF, Schatzberg A, Andersen SW, Van Campen LE, et al. A double-blind, randomized study of olanzapine and olanzapine/fluoxetine combination for major depression with psychotic features. J Clin Psychopharmacol 2004;24:365-73.

51. Meyers BS, Flint AJ, Rothschild AJ, Mulsant BH, Whyte EM, Peasley-Miklus C, et al. A double-blind randomized controlled trial of olanzapine plus sertraline vs olanzapine plus placebo for psychotic depression: the study of pharmacotherapy of psychotic depression (STOP-PD). Arch Gen Psychiatry 2009;66:838-47.

52. Brunner E, Tohen M, Osuntokun O, Landry J, Thase ME. Efficacy and safety of olanzapine/fluoxetine combination vs fluoxetine monotherapy following successful combination therapy of treatment-resistant major depressive disorder. Neuropsychopharmacology 2014;39:2549-59.

53. Rocca P, Marchiaro L, Rasetti R, Rivoira E, Bogetto F. A comparison of paroxetine versus paroxetine plus amisulpride in the treatment of dysthymic disorder: efficacy and psychosocial outcomes. Psychiatry Res 2002;112:145-52.

54. Rocca P, Fonzo V, Ravizza L, Rocca G, Scotta M, Zanalda E, et al. A comparison of paroxetine and amisulpride in the treatment of dysthymic disorder. J Affect Disord 2002;70:313-7.

55. Zanardi R, Smeraldi E. A double-blind, randomised, controlled clinical trial of acetyl-L-carnitine vs. amisulpride in the treatment of dysthymia. Eur Neuropsychopharmacol 2006;16:281-7.

56. Cassano GB, Jori MC. Efficacy and safety of amisulpride $50 \mathrm{mg}$ versus paroxetine $20 \mathrm{mg}$ in major depression: a randomized, double-blind, parallel group study. Int Clin Psychopharmacol 2002;17:27-32.

57. Ravizza L. Amisulpride in medium-term treatment of dysthymia: 
a six-month, double-blind safety study versus amitriptyline. AMILONG investigators. J Psychopharmacol 1999;13:248-54.

58. Boyer P, Lecrubier Y, Stalla-Bourdillon A, Fleurot O. Amisulpride versus amineptine and placebo for the treatment of dysthymia. Neuropsychobiology 1999;39:25-32.

59. Smeraldi E. Amisulpride versus fluoxetine in patients with dysthymia or major depression in partial remission: a double-blind, comparative study. J Affect Disord 1998;48:47-56.

60. Lecrubier Y, Boyer P, Turjanski S, Rein W. Amisulpride versus imipramine and placebo in dysthymia and major depression. Amisulpride Study Group. J Affect Disord 1997;43:95-103.

61. León CA, Vigoya J, Conde S, Campo G, Castrillón E, León A. Comparison of the effect of amisulpride and viloxazine in the treatment of dysthymia. Acta Psiquiatr Psicol Am Lat 1994;40:41-9.

62. Amore M, Jori MC. Faster response on amisulpride $50 \mathrm{mg}$ versus sertraline 50-100 mg in patients with dysthymia or double depression: a randomized, double-blind, parallel group study. Int Clin Psychopharmacol 2001;16:317-24.

63. Mahmoud RA, Pandina GJ, Turkoz I, Kosik-Gonzalez C, Canuso CM, Kujawa MJ, et al. Risperidone for treatment-refractory major depressive disorder: a randomized trial. Ann Intern Med 2007;147:593-602.

64. Keitner GI, Garlow SJ, Ryan CE, Ninan PT, Solomon DA, Nemeroff CB, et al. A randomized, placebo-controlled trial of risperidone augmentation for patients with difficult-to-treat unipolar, non-psychotic major depression. J Psychiatr Res 2009;43: 205-14.

65. Reeves H, Batra S, May RS, Zhang R, Dahl DC, Li X. Efficacy of risperidone augmentation to antidepressants in the management of suicidality in major depressive disorder: a randomized, double-blind, placebo-controlled pilot study. J Clin Psychiatry 2008;69:1228-336.

66. Rapaport MH, Gharabawi GM, Canuso CM, Mahmoud RA, Keller $\mathrm{MB}$, Bossie CA, et al. Effects of risperidone augmentation in patients with treatment-resistant depression: Results of open-label treatment followed by double-blind continuation. Neuropsychopharmacology 2006;31:2505-13.

67. Alexopoulos GS, Canuso CM, Gharabawi GM, Bossie CA, Greenspan A, Turkoz I, et al. Placebo-controlled study of relapse prevention with risperidone augmentation in older patients with resistant depression. Am J Geriatr Psychiatry 2008;16:21-30.

68. Papakostas GI, Vitolo OV, Ishak WW, Rapaport MH, Zajecka JM, Kinrys G, et al. A 12-week, randomized, double-blind, placebo-controlled, sequential parallel comparison trial of ziprasidone as monotherapy for major depressive disorder. J Clin Psychiatry 2012;73:1541-7.

69. Jeon HJ, Fava M, Mischoulon D, Baer L, Clain A, Doorley J, et al. Psychomotor symptoms and treatment outcomes of ziprasidone monotherapy in patients with major depressive disorder: a 12-week, randomized, double-blind, placebo-controlled, sequential parallel comparison trial. Int Clin Psychopharmacol 2014;29:332-8.

70. Heo JY, Jeon HJ, Fava M, Mischoulon D, Baer L, Clain A, et al. Efficacy of ziprasidone monotherapy in patients with anxious depression: a 12-week, randomized, double-blind, placebo-controlled, sequential-parallel comparison trial. J Psychiatr Res
2015;62:56-61.

71. Papakostas GI, Fava M, Baer L, Swee MB, Jaeger A, Bobo WV, et al. Ziprasidone augmentation of escitalopram for major depressive disorder: efficacy results from a randomized, double-blind, placebo-controlled study. Am J Psychiatry 2015;172:1251-8.

72. McCormack PL. Cariprazine: first global approval. Drugs 2015;75:2035-43.

73. Citrome L. Cariprazine: chemistry, pharmacodynamics, pharmacokinetics, and metabolism, clinical efficacy, safety, and tolerability. Expert Opin Drug Metab Toxicol 2013;9:193-206.

74. Yang FW, Liang CS. Paliperidone augmentation for treatment-resistant depression: a case report. J Clin Psychopharmacol 2011;31:245-6.

75. Suppes T, Silva R, Cucchiaro J, Mao Y, Targum S, Streicher C, et al. Lurasidone for the treatment of major depressive disorder with mixed features: a randomized, double-blind, placebo-controlled study. Am J Psychiatry 2016;173:400-7.

76. Fountoulakis KN, Nimatoudis I, Iacovides A, Kaprinis G. Off-label indications for atypical antipsychotics: a systematic review. Ann Gen Hosp Psychiatry 2004;3:4.

77. Papakostas GI, Shelton RC, Smith J, Fava M. Augmentation of antidepressants with atypical antipsychotic medications for treatment-resistant major depressive disorder: a meta-analysis. J Clin Psychiatry 2007;68:826-31.

78. Nelson JC, Papakostas GI. Atypical antipsychotic augmentation in major depressive disorder: a meta-analysis of placebo-controlled randomized trials. Am J Psychiatry 2009;166:980-91.

79. Pae CU. Why Systematic review rather than narrative review? Psychiatry Investig 2015;12:417-9.

80. Arbaizar B, Dierssen-Sotos T, Gómez-Acebo I, Llorca J. Aripiprazole in major depression and mania: meta-analyses of randomized placebo-controlled trials. Gen Hosp Psychiatry 2009;31:478-83.

81. Maneeton N, Maneeton B, Srisurapanont M, Martin SD. Quetiapine monotherapy in acute phase for major depressive disorder: a meta-analysis of randomized, placebo-controlled trials. BMC Psychiatry 2012;12:160.

82. Spielmans GI, Berman MI, Linardatos E, Rosenlicht NZ, Perry A, Tsai AC. Adjunctive atypical antipsychotic treatment for major depressive disorder: a meta-analysis of depression, quality of life, and safety outcomes. PLoS Med 2013;10:e1001403.

83. Wen XJ, Wang LM, Liu ZL, Huang A, Liu YY, Hu JY. Meta-analysis on the efficacy and tolerability of the augmentation of antidepressants with atypical antipsychotics in patients with major depressive disorder. Braz J Med Biol Res 2014;47:605-16.

84. Shelton RC. What are the comparative benefits and harms of augmentation treatments in major depression? J Clin Psychiatry 2015;76:e531-3.

85. Zhou X, Ravindran AV, Qin B, Del Giovane C, Li Q, Bauer M, et al. Comparative efficacy, acceptability, and tolerability of augmentation agents in treatment-resistant depression: systematic review and network meta-analysis. J Clin Psychiatry 2015;76: e487-98.

86. Zhou X, Keitner GI, Qin B, Ravindran AV, Bauer M, Del Giovane $\mathrm{C}$, et al. Atypical antipsychotic augmentation for treatment-resistant depression: a systematic review and network meta-analysis. Int J Neuropsychopharmacol 2015;18. doi: 10.1093/ijnp/pyv060. 
87. Wang HR, Woo YS, Ahn HS, Ahn IM, Kim HJ, Bahk WM. Can atypical antipsychotic augmentation reduce subsequent treatment failure more effectively among depressed patients with a higher degree of treatment resistance? A meta-analysis of randomized controlled trials. Int $\mathrm{J}$ Neuropsychopharmacol 2015;18. doi: 10.1093/ijnp/pyv023.
88. Quante A, Regen F, Schindler F, Volkmer K, Severus E, Urbanek $\mathrm{C}$, et al. Quetiapine as combination treatment with citalopram in unipolar depression with prominent somatic symptoms: a randomised, double-blind, placebo-controlled pilot study. Psychiatr Danub 2013;25:214-20. 